\title{
レーザー超音波法による炭素鋼中の内部欠陥の非接触検出
}

\author{
田中 崇雄, 井澤 靖和* \\ (財) レーザー技術総合研究所 (テ550-0004 大阪市西区靫本町1丁目8番4号) \\ *大阪大学レーザー核融合研究センター（テ565-0871 大阪府吹田市山田丘2番6号）
}

\section{Noncontact Detection of Internal Defects in Carbon Steel by Laser Ultrasonics}

\author{
Takao TANAKA and Yasukazu IZAWA* \\ Institute for Laser Technology, 1-8-4 Utsubohommachi, Nishi-ku, Osaka 550-0004 \\ *Institute of Laser Engineering, Osaka University, 2-6 Yamadaoka, Suita, Osaka 565-0871
}

(Received Octorber 15, 2001)

\begin{abstract}
Cylindrical internal defects in carbon steel specimens were detected noncontactly and nondestructively from the measurements of ultrasonic diffraction signals using the laser ultrasonic technique. Laser beams used for both ultrasonic generation and detection have a $0.7-\mathrm{mm}$ diameter. Spatial profiles of the diffracted ultrasonic amplitude were measured for the internal defects of 0.5 to $5.0 \mathrm{~mm}$ in diameter, which were in good agreement with the profiles calculated by using Cornu's spiral. This method can be useful for the noncontact detection of internal defects in metal, and is considered to be applicable to the noncontact sizing of the internal defects such as those in power plant components.
\end{abstract}

Key Words: Laser ultrasonics, Internal defect, Noncontact detection, Fresnel diffraction, Cornu's spiral

\section{1. はじめに}

電力プラントの安全運転のためには, 構造材料中に発生 した欠陥をできるだけ早期に検出し, 必要に応じて修繥, 部 材取替え等を実施することが必要不可欠である。また, 欠 陥の検出のみならず, プラント部材の経年劣化の評価や余 寿命の予測を行うことは, プラント設備管理の効率化につ ながり, 定期点検期間の短縮, 部材調達の効率化などコス 卜低減効果が大きく, 産業界から強く切望されている技術 である。

現在行われているプラント部材の材料検査の中でも非 破壊検査は, 材料表面あるいは材料内部に存在する欠陷や 不連続部を, 部材を傷つけることなく外部から調べること ができる有益な検査手法である。非破壊検査のうち, 超音 波探傷試験は, 比較的簡便に材料内部の欠陥を検出するこ とが可能なため, 例えば, 原子力発電所における原子炉容 器の溶接部, 火力発電所におけるボイラー, 蒸気タービン 等, プラント部材の重要部分の検査に広く用いられてい る.

金属材料に超音波の送受信を行う装置としては, 圧電素 子が最も一般的に用いられており, 圧電素子による超音波 探傷試験は,一つの確立した検査技術となっている。しか しながら, 圧電素子を用いる場合, 測定者が試験対象部材 に接近しなければならないため, 放射線区域, 高温区域等 の悪環境条件下での測定が困難であり, また, 狭隘部等の 測定も困難である。
一方, 最近のレーザー技術は著しく進歩しており, その 応用技術であるレーザー超音波探傷法は, 非破壊検査の分 野における検査技術として盛んに研究・開発が行われて いる1,2).このレーザー超音波探傷法は, パルスレーザー光 を材料表面に照射して, 材料表面あるいは材料内部に超音 波を発生・伝播させ,伝播した超音波による材料表面の微 小振動をレーザー干渉計により受信する, 非破壊検査技術 である。この技術は, レーザーを用いて非接触で超音波の 送受信を行うことができるため, 遠隔操作による悪環境条 件下での検査が可能になるという利点を有している。ま た, 狭险部の測定においては, これまで超音波顕微鏡等に よる超音波ビーム集束技術3) があるが, レーザー超音波法 は, レーザー光の集光等により, ある程度離れた場所から 狭险部の測定を行うことが可能になるものと考えられる。

パルスレーザー光を金属材料に照射すると, 縦波, 横波, 表面波等, 多様な超音波が発生するが, 表面波は伝播に伴 う減衰が少ないため4), これまでのレーザー超音波探傷技 術では, 表面波を用いた表面欠陥の検出が中心であった。 しかしながら,プラント部材において, 久陥は材料表面だ けでなく材料内部にも存在するため, 表面波だけでは全て の久陥を検出することができない。一方, 縦波と横波は不 透明な金属材料の内部を伝播し, 内部欠陷を検出するのに 非常に有効であることから，このレーザー超音波探傷技術 を内部欠陥の検出に応用することが必要とされているが, 材料の内部方向へ伝播する縦波と横波は, 伝播に伴う減衰 が大きいため,レーザー超音波探傷技術を利用した材料内 
部の欠陷検出は, わずかしか報告例がない5,6).

これまで我々は, QスイッチNd:YAGレーザー照射により 炭素鋼内部に発生させた超音波縦波を, CWレーザーと ファブリーペロー干渉計を用いたレーザー干渉計により 受信する, レーザー超音波送受信装置を作製し, 非接触で 炭素鋼内部の微小欠陥の検出を試み, 最小で直径 $100 \mu \mathrm{m}$ の 長円柱形内部欠陥の非接触検出を行った ${ }^{6)}$. これは内部欠 陥により反射した超音波信号を受信したものであるが, 内 部欠陥の形状によっては, 反射波の進行方向が大きく変わ るため, 反射波の存在を見落としてしまう可能性がある。

一方, 内部欠陥を回折した超音波信号を用いると, 超音波 受信点が超音波発生点から見て内部欠陥のかげとなる領 域では, 受信される超音波信号が弱くなることから,この 超音波信号の測定によっても, 非接触で材料内部の欠陥検 出が可能となるものと考えられる。この手法では, 受信さ れる超音波信号が内部欠陥の形状にあまり依存せず, 内部 欠陷検出の信頼性が向上するものと考えられるため, 本論 文では, レーザー超音波送受信装置を用いて, 内部欠陷を 回折した超音波信号の測定を行うことにより, 炭素鋼試験 片中の模擬内部欠陥の非接触検出を行ったので報告する.

\section{2. 測定原理}

\section{1 レーザー超音波送受信装置}

レーザーにより超音波の送受信を行う装置の概略図を Fig. 1に示す。超音波発生用レーザーには, Qスイッチ Nd: YAGレーザーの基本波を用いた。レーザーのパルス幅は 約 $11 \mathrm{~ns}$, 繰り返し周波数は $10 \mathrm{~Hz}$ であり, 試験片の手前にピ ンホールを配置することにより, 照射ビーム径を約 $0.7 \mathrm{~mm}$

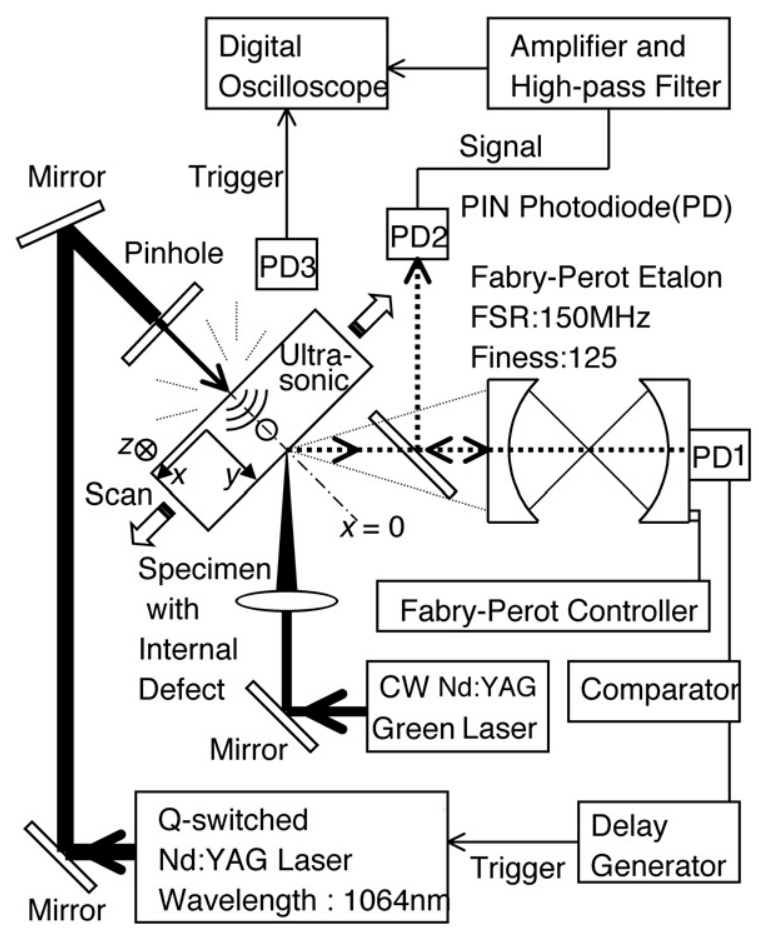

Fig. 1 Experimental setup for detection of internal defects in carbon steel by laser ultrasonic technique.
とした。このピンホールを通して試験片に照射された レーザーエネルギーは約 $1.8 \mathrm{~mJ} /$ パルスであった. 超音波 受信用のレーザーには, LD励起のシングルモードCW Nd: YAGレーザーの2倍高調波を用いた。レーザーの出力は $210 \mathrm{~mW}$, スペクトル幅は $10 \mathrm{kHz}$ 以下であり, 光学レンズで 集光することにより, 照射位置におけるビーム径を約 0.7 $\mathrm{mm}$ とした.ファブリーペロー干渉計は, 共焦点型であり, 自由スペクトル幅 (FSR)は $150 \mathrm{MHz}$, フィネスは125であ る. CW Nd:YAGレーザーからの光は試験片表面で反射さ れた後, ファブリーペロー干渉計に導かれ, 透過光および 反射光をPINフォトダイオードであるPD1およびPD2を用 いてそれぞれ検出し, PD1出力電圧をQスイッチ $\mathrm{Nd}$ : YAG レーザーのトリガーとして, PD2出力電圧を計測信号とし て用いた。

CW Nd:YAGレーザーには, わずかな周波数変動が存在 し, また,ファブリーペロー干渉計は環境温度により共振 器間隔が変化するため,これらは測定誤差の要因となるが, 本測定装置は, Fig. 2に示すトリガタイミングにより, 最大 感度で, かつ安定して超音波信号が受信されるような構成 となっている。まず,ファブリーペロー干渉計に取り付け られた圧電素子に, Fig. 2 (a) に示すような三角波の電圧を $5 \mathrm{~Hz}$ で印加して, 干涉計の共振器間隔を掃引することによ り,Fig. 2(b)に示されるような共振波形が現れる. Fig. 2(a) の三角波の谷と山の時間間隔は約 $180 \mathrm{~ms}$ であり,フィネス が125であるため, Fig. 2(b)の共振波形の時間幅は約 $1.4 \mathrm{~ms}$ となる. Fig. 2(b)において, ファブリーペロー透過光強度 であるPD1出力電圧が, この共振波形のピーク高さの半分

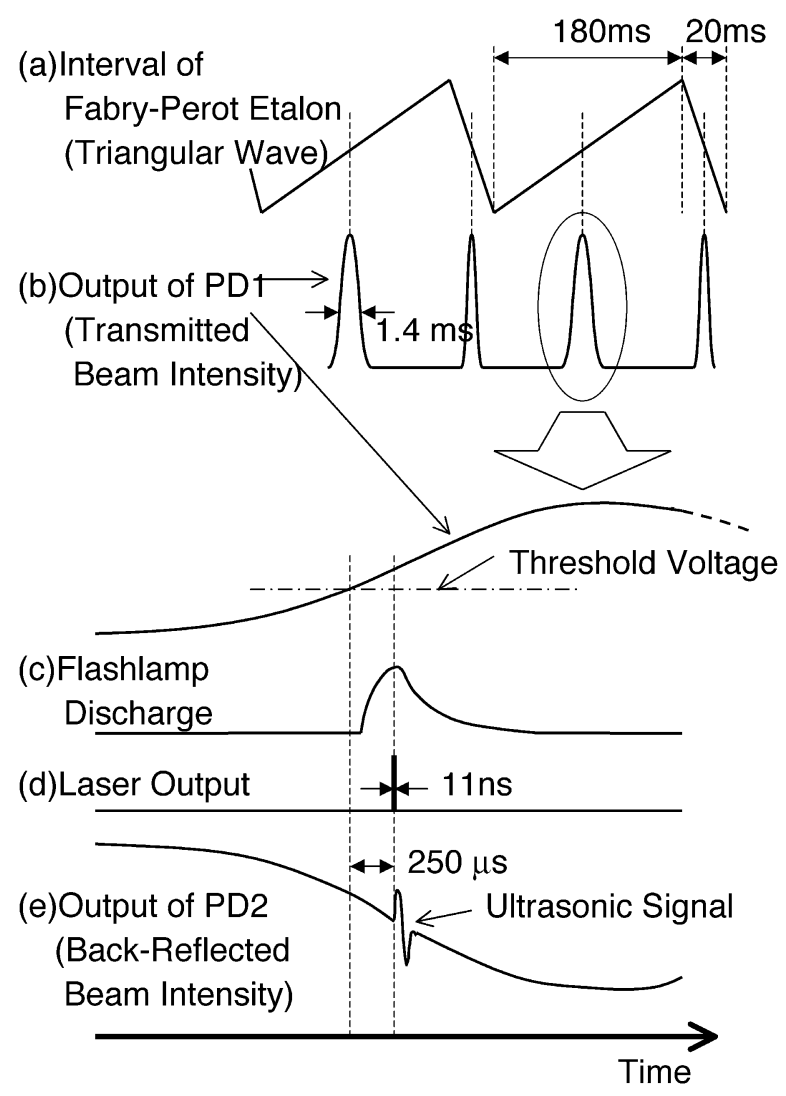

Fig. 2 Chronograph of the laser ultrasonic system. 
になるときに, PD1出力電圧の変化率が最大となり, レー ザー干渉計の感度が最大となるため, この夕イミングで, 超 音波を発生させるよう, Fig. 1に示すコンパレータ回路のし きい值電圧を調整した。コンパレータ回路からの信号に より,QスイッチNd:YAGレーザーのフラッシュランプヘの 放電を開始し, 放電開始から約 $250 \mu \mathrm{s}$ 後に, Qスイッチが動 作し,パルスレーザー光が試験片に照射される。これを Fig. 2(c) およびFig. 2(d)に示す. Qスイッチレーザー光照 射により発生・伝播した超音波により受信側の試験片表 面が微小振動するため, CW Nd:YAGレーザー光はドップ ラーシフトを受け, このシフト量に応じてレーザー光周波 数が変化する. このレーザー光周波数の変化に比例して ファブリーペロー干渉計の反射光強度が変化するため, 最 終的に超音波信号がファブリーペロー干渉計の反射光強 度で表されることになり,これをPD2により Fig. 2(e)のよ うな信号として受信した。 この手法により, CW Nd:YAG レーザーの周波数変動や, 環境温度の変化に対して, 常に 測定装置の超音波受信感度が最大になるように保たれ, 測 定誤差を非常に小さくすることが可能となった。

また, 計測信号としてファブリーペロー透過光ではな くファブリーペロー反射光を使用する理由は, 透過光は超 音波の周波数が高い領域において, 周波数が高くなるにつ れて超音波受信感度が低下するのに対して, 反射光は超音 波の周波数が高い領域においても, 超音波受信感度が一定 に保たれるためである7). 超音波計測信号は, 低周波フィ ルタおよび増幅器を通過した後, デジタルオシロスコープ でAD変換され, 30 ショットを平均した波形を記録した。

\section{2 模擬内部欠㫟試験片の仕様}

厚さ $20 \mathrm{~mm}$ の炭素鋼試験片に, 長円柱形の穴を空けて模 擬内部欠陷を作製した. Fig. 1に示すように試験片のx,y,z 軸を定めると, 模擬内部欠陥の長円柱の軸はz軸方向であ り, 長円柱の直径としては, $0.5 \mathrm{~mm}, 1.0 \mathrm{~mm}, 3.0 \mathrm{~mm}$ および $5.0 \mathrm{~mm}$ を用いた。長円柱形の横穴は, Qスイッチ Nd:YAG レーザー照射面, およびCW Nd:YAGレーザー照射面から は, 目視により確認できないものであるため, 模擬的な内 部欠陥であるとみなすことが可能である。ここで, 超音波 受信面と模擬内部欠陥中心との距離を $7.5 \mathrm{~mm}$ に設定し た.また, Qスイッチレーザー光を試験片に照射したとき に発生する超音波縦波の指向性は, 試験片表面に対して垂 直方向が最大となるため, 受信用CW YAGレーザー光の照 射点は, 常にQスイッチレーザー光の照射点から $y$ 軸方向に 伸ばした線上になるように固定した。この状態で, 模擬内 部欠陥の長円柱の軸が超音波伝播経路を横切るよう, $x$ 軸方 向に試験片を精密ステージで移動させることにより,レー ザー光を走査して非接触で内部欠陥の位置を検出してい るとみなすことが可能となる。

\section{3. 測定結果}

3.1 円柱形内部欠陥を走査させたときの超音波信号 の変化

Fig. 1の装置を用いて, 模擬内部欠陥のない試験片にレー
ザー超音波の送受信を行った超音波波形例をFig. 3に示 す. Fig. 3において, $3.4 \mu \mathrm{s}$ 付近に現れる信号は超音波縦波 第1波であり,引き続き, 試験片表面での縦波反射による多 重反射エコーが観測された。 また, Fig. 3において, $6.3 \mu \mathrm{s}$ 付近に現れる信号は超音波横波第1波である。これらの超 音波信号は, 炭素鋼中における縦波および横波の音速と試 験片の厚さから計算される超音波伝播時間と一致するこ とからも確認される. 超音波の伝播経路に内部欠陥が存 在すると, 超音波は反射, 散乱, および回折を受けて, 波形 が変化するため,これらを観測することにより試験片中の 内部欠陥が検出される。

まず, 超音波の伝播経路を横切るよう, 直径 $5.0 \mathrm{~mm}$ の長 円柱形欠陥をFig. 1の $x$ 軸方向に走査させ, 各欠陥位置にお ける縦波第1波の受信電圧をプロットしたものをFig.4に示 す。横軸は, QスイッチNd:YAGレーザー照射面の中心から Fig. 1のy軸方向に伸ばした線上に, 模擬内部欠陥の中心が 存在する場合の欠陷位置を $0.0 \mathrm{~mm}$ に定めた。また, 試験片 表面の荒れにより,レーザー干渉計の感度は試験片を走査 するたびに変動し, PD2から出力される電圧に影響を与え るが, レーザー干渉計の感度も同時に測定し, 試験片に欠 陥がない場合に1になるよう, PD2出力電圧の規格化を行っ た。

Fig. 4のプロットより, 久陥の位置が $0.0 \mathrm{~mm}$ 付近の場合 に, PD2出力電圧が大きく減少することが観測された。ま た, その最小值は, 久陷が十分離れている場合のPD2出力電 圧の0.16倍程度であった。これは, 超音波の送受信を行う レーザービーム径よりも, 模擬内部欠陥の直径の方が数倍 大きく, 発生した超音波の大部分は欠陥で反射, 散乱され たためであると考えられる。また, 欠陥の位置が $\pm 4.5 \mathrm{~mm}$ 付近の場合, すなわち, レーザー光照射点が内部欠陥の幾 何学的なかげの縁 $( \pm 2.5 \mathrm{~mm})$ から約 $2 \mathrm{~mm}$ 程度離れている 場合において, PD2出力電圧は最大值を示した.

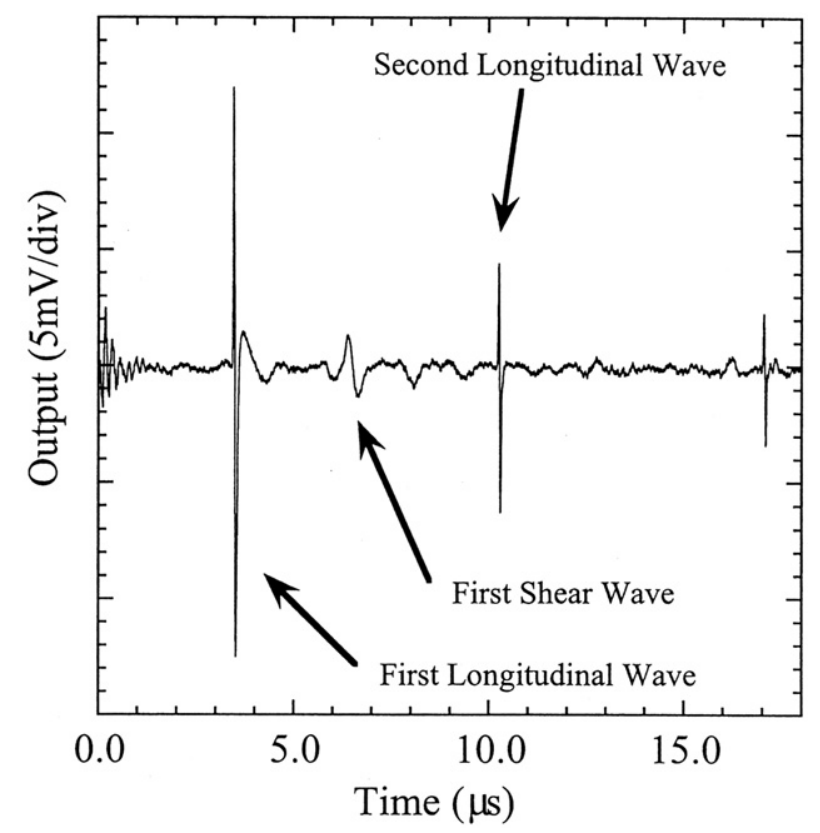

Fig. 3 An example of ultrasonic waveform measured without internal defect. 


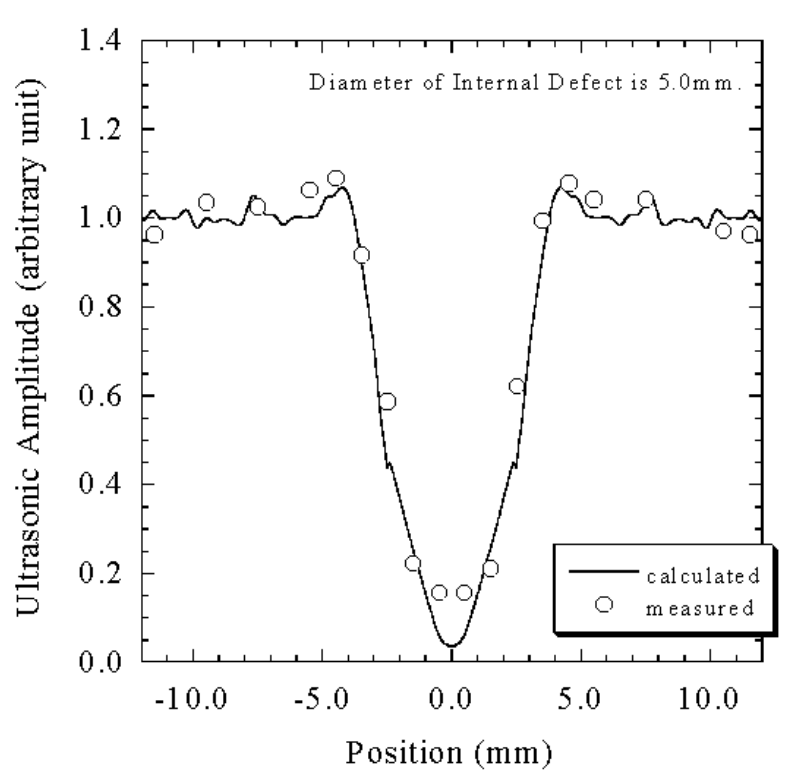

Fig. 4 Spatial profile of the ultrasonic amplitude. Diameter of internal defect is $5.0 \mathrm{~mm}$.

次に, 直径 $3.0 \mathrm{~mm}$ の長円柱形欠陥を走査させ, 規格化し たPD2出力電圧をプロットしたものをFig. 5に示す. 横軸 はFig. 4と同様に定めた. Fig. 5のプロットにおいても, 模 擬内部欠陥の直径の方がレーザービーム径よりも大きい ため, Fig. 4 と同様に, 久陥の位置が $0.0 \mathrm{~mm}$ 付近の場合に, PD2出力電圧が大きく減少することが観測され, その最小 值は欠陥が十分離れている場合の0.19倍程度であった。ま た, 久陉の位置が $\pm 3.5 \mathrm{~mm}$ 付近の場合, すなわちFig. 4と同 様に, レーザー光照射点が内部欠陥の幾何学的なかげの縁 $( \pm 1.5 \mathrm{~mm})$ から約 $2 \mathrm{~mm}$ 程度離れている場合において, PD2 出力電圧は最大となった。

次に, 直径 $1.0 \mathrm{~mm}$ の長円柱形欠陥を走査させ, 規格化し たPD2出力電圧をプロットしたものをFig. 6に示す. Fig. 6

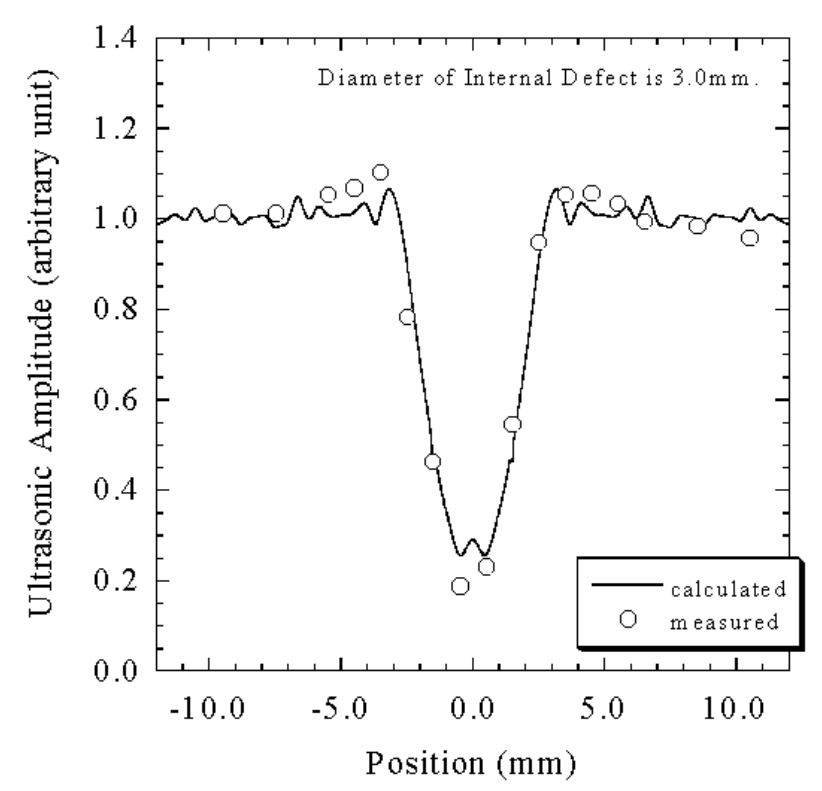

Fig. 5 Spatial profile of the ultrasonic amplitude. Diameter of internal defect is $3.0 \mathrm{~mm}$.

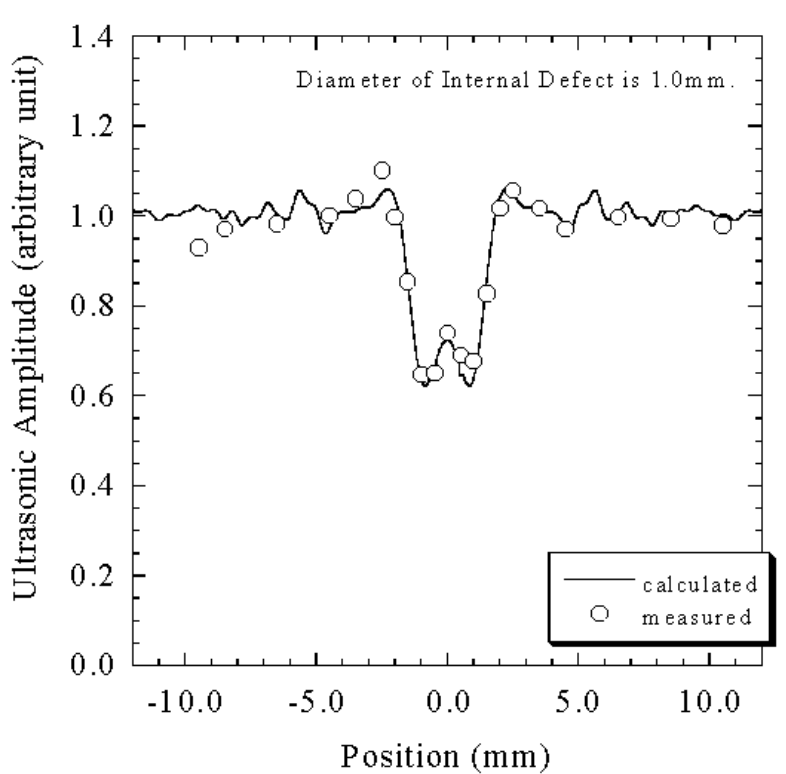

Fig. 6 Spatial profile of the ultrasonic amplitude. Diameter of internal defect is $1.0 \mathrm{~mm}$.

のプロットにおいては, PD2出力電圧は欠陥の位置が \pm 1.0 $\mathrm{mm}$ の場合に最小となり, $0.0 \mathrm{~mm}$ の場合に極大となること が観測された。 $0.0 \mathrm{~mm}$ 付近に模擬内部欠陥が存在する場 合のPD2出力電圧は, Fig. 4およびFig. 5ほど著しくは減少 しておらず, PD2出力電圧の最小值は, 久陥が十分離れてい る場合の 0.65 倍程度であった。これは, 内部欠陥の直径が レーザービーム径と同程度であり, 内部欠陥で反射, 散乱 され, 損失を受ける超音波成分が減少したためであると考 えられる。また, 久陥の位置が $0.0 \mathrm{~mm}$ の場合は, 欠陥の左 右から回折した，それぞれの超音波の位相が一致するため， PD2出力電圧が極大值となって観測されたものと考えられ る. 一方, PD2出力電圧の最大值は, 久陥の位置が $\pm 2.5 \mathrm{~mm}$ 付近の場合, すなわち, レーザー光照射点が内部欠陥の幾 何学的なかげの縁 $( \pm 0.5 \mathrm{~mm})$ から約 $2 \mathrm{~mm}$ 程度離れている 位置において観測された。

最後に, レーザービーム径よりも小さな, 直径 $0.5 \mathrm{~mm}$ の 長円柱形欠陥を走査させ, 規格化したPD2出力電圧をプ ロットしたものをFig. 7に示す. Fig. 7のプロットにおいて も, Fig. 6 と同様に, $0.0 \mathrm{~mm}$ の久㫟位置において, PD2出力 電圧の極大值が観測された. PD2出力電圧の最小值は, 久 陥が十分離れている場合の0.84倍程度であった。 また, Fig. 4, Fig. 5, およびFig. 6 と同様に, レーザー光照射点が内部 欠陥の幾何学的なかげの縁 $( \pm 0.25 \mathrm{~mm})$ から約 $2 \mathrm{~mm}$ 程度離 れている位置において, PD2出力電圧の最大值が観測さ れた。

Fig. 4およびFig. 5より, 超音波の送受信径, すなわちレー ザービーム径より, 数倍以上大きな模擬内部欠陥が超音波 伝播経路に存在する場合, 発生した超音波の大部分は, 久 陥で反射, 散乱されるために, PD2出力電圧が著しく減少す ることが観測された。 また, Fig. 6およびFig. 7より,模擬内 部欠陉が, 超音波の送受信径と同程度か, それより小さい 場合においても, PD2出力電圧が減少することが示され た。これらの測定により,レーザー超音波法を用いてレー 


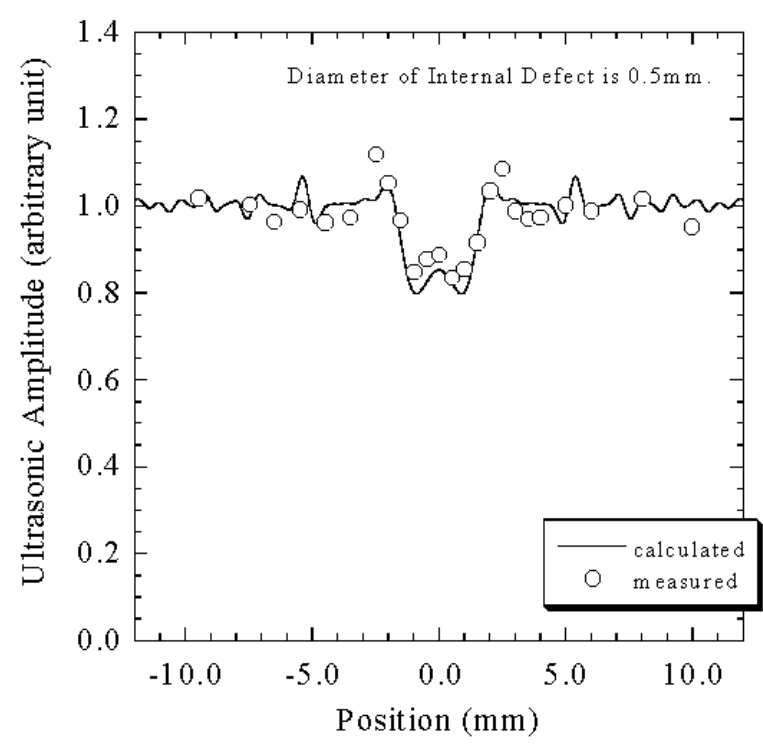

Fig. 7 Spatial profile of the ultrasonic amplitude. Diameter of internal defect is $0.5 \mathrm{~mm}$.

ザー光を走査し, PD2出力電圧の変化を調べることにより, 非接触で金属材料の内部欠陥の探傷が可能となることが 示された。また, 本測定により,レーザー超音波探傷法は, ある程度離れた場所から狭险部の測定を行う手法として 有効である可能性が示された。

\section{2 内部欠陥による超音波回折の理論計算}

試験片中を伝播する超音波は, 内部欠陥により回折す る。そこで, 長円柱形欠陥による超音波の回折を理論的に 計算し, 本測定結果との比較を行った。回折現象はFraunhofer回折とFresnel回折に分類されるが, 本測定は, 障害物で ある模擬内部欠陥と超音波受信面が近距離にあるため, Fresnelの回折理論が当てはまるものと考えられる.

Fresnel回折の条件に扔いて, 波が長円柱形の障害物によ り回折する場合,受信面に执ける波の振幅を求めるには, コ ル又の螺旋 (Cornu's spiral $)^{8)}$ を用いた手法が簡便であり,こ の手法を用いて, 本測定条件のように内部欠陥を走査した 場合の,超音波振幅分布の計算を行った。この計算に必要 なパラメータは, 超音波の波長, 音源と障害物との距離, 障 害物と受信点との距離, 障害物の大きさおよび位置であり, 超音波の波長以外は既知である。そこで, 試験片を伝播し ている超音波の波長を見積もるために, 超音波の周波数特 性の測定を行った。これは受信超音波信号に高速フーリ 工変換 $(\mathrm{FFT})$ を行うことにより求められる.

まず,内部欠陥のない試験片を伝播する超音波縦波第 1 波 についてFFTを行った波形をFig. 8に示す. Fig. 8より,本 測定装置により炭素鋼中に発生した超音波は, 広い周波数 帯域を有しており,また $5.0 \mathrm{MHz}$ 付近に周波数ピークを有 していることが分かる．炭素鋼中の超音波縦波の音速は 約 $5,900 \mathrm{~m} / \mathrm{s}$ であるため9), これより超音波の波長は約 1.2 $\mathrm{mm}$ の成分が最も多いものと見積もられる。

測定結果との比較を行うため, 直径 $5.0 \mathrm{~mm}, 3.0 \mathrm{~mm}, 1.0$ $\mathrm{mm}$, 抢よび $0.5 \mathrm{~mm}$ の長円柱形欠陥を走査した場合の幾何

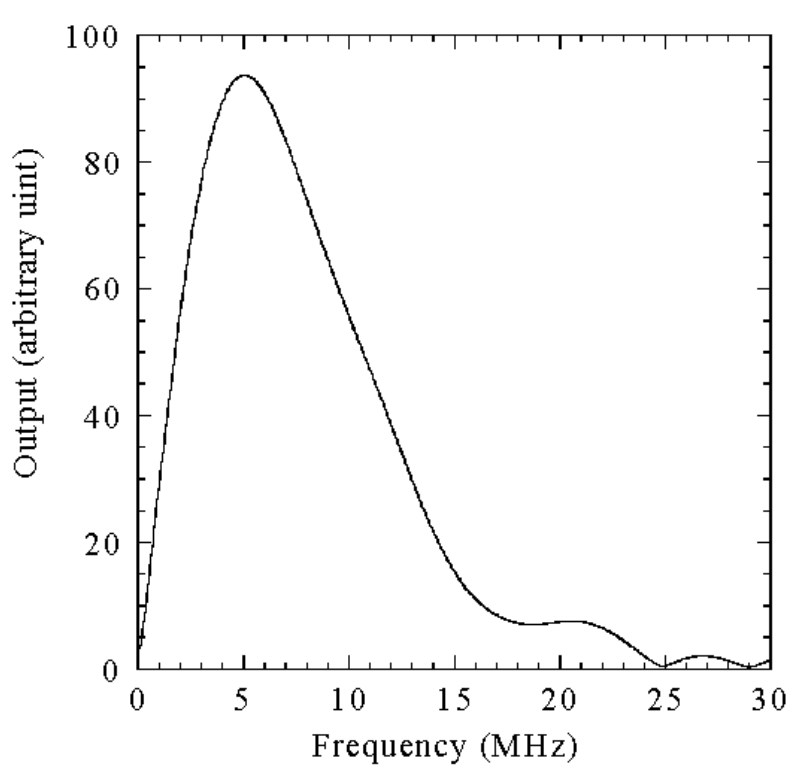

Fig. 8 Frequency spectrum of the first longitudinal wave measured without internal defect.

学的パラメータと,この超音波の波長から, コル又の螺旋 を用いて, 長円柱形欠陥によるFresnel回折後の超音波振幅 分布の計算を行った。な招,発生した超音波はFig. 8に示さ れるような広い周波数帯域を有しているため, 各周波数ご とに超音波振幅を繰り返し計算して重㸚合わせを行い,ま た,超音波の送受信面に扔いても, レーザービーム径 $0.7 \mathrm{~mm}$ の中の各点ごとに, 繰り返し計算して重稀わせを行うこ とにより,超音波周波数の広がり掠よび送受信点の広がり を考慮した。

計算により求められる超音波振幅は, 測定により得られ るPD2出力電圧に比例するため, 内部欠陥の直径が $5.0 \mathrm{~mm}$, $3.0 \mathrm{~mm}, 1.0 \mathrm{~mm}$, 㧍よび $0.5 \mathrm{~mm}$ の場合に抢ける超音波振幅 分布の計算結果を,それぞれFig. 4, Fig. 5, Fig. 6, およびFig. 7中の実線で示す。超音波振幅分布の計算結果は, 久陥の左 右から回折した超音波が互いに干渉することにより,複雑 な振幅振動を示すが, いずれの直径においても, 音源から 見て受信点が内部欠陥の幾何学的なかげとなる領域では, 超音波振幅が減少した。しかしながら, 幾何学的なかげの 中心, すなわち $0.0 \mathrm{~mm}$ の位置では, 欠陥の左右から回折し た超音波の位相が一致するため, 内部欠陥直径が5.0 mmの 場合を除き, 超音波振幅は極大を示した。また,いずれの 欠陥直径に対しても,内部欠陥の幾何学的なかげの縁から 約 $2 \mathrm{~mm}$ 離れた位置において, 超音波振幅は最大值を示し た.

これらの計算結果と測定プロットとの比較を行うと, 測 定結果は計算結果とよく似た傾向を示した。特に, Fig. 6お よびFig. 7では, 幾何学的なかげの中心で超音波振幅が極大 を示す現象が, 測定においても観測された。また,いずれ の欠陥直径に対しても, 超音波の送受信点が内部欠陥の幾 何学的なかげの縁から約 $2 \mathrm{~mm}$ 程度離れている場合に, Fresnel 回折の効果により, PD2出力電圧が最大值を示した。 よっ て,レーザー光を走査させたときの, PD2出力電圧の変化の 情報から, 金属材料中の内部欠陥の寸法を推測することも 
可能であると考えられる。

本測定結果により,レーザー超音波法による金属材料の 探傷において, 内部欠陥により反射した超音波信号からだ けでなく, 内部欠陥により回折した超音波信号からも, 非 接触で内部欠陥の検出が可能であることが示された。本 測定により検出された, 直径 $0.5 \mathrm{~mm}$ か $5.0 \mathrm{~mm}$ の内部欠陥 は, 従来の圧電素子を用いた探傷法でも十分検出可能なも のであるが, レーザー超音波法の非接触という利点を生か すことにより, 悪環境条件下での非破壊検査が可能になる ものと考えられる。

\section{4. まとめ}

炭素鋼試験片に長円柱形の模擬内部欠陥を作製し, レー ザー超音波送受信装置を用いて, レーザービーム径 $0.7 \mathrm{~mm}$ で超音波の送受信を行った。超音波の伝播経路を横切る よう, 長円柱形内部欠陥を走査した場合の超音波信号を測 定した結果, 超音波振幅は, 内部欠陥の幾何学的なかげの 中に超音波受信点がある場合に減少し, 内部欠陥の幾何学 的なかげの縁から超音波受信点が $2 \mathrm{~mm}$ 程度離れた場合に 最大になることが観測された。また, 簡便な手法として,コ ルヌの螺旋を用いて内部欠陥を走査した場合の超音波振 幅分布の理論計算を行った結果, 計算結果は測定結果を裏
付けるものであることが示された。これらの測定結果よ り, レーザー超音波探傷法は, 非接触で, 炭素鋼中のmmオー ダー以下の内部欠陥が検出可能であることが示された。 さらに, 内部欠陥により回折した超音波信号の測定と, 内 部欠陥により反射した超音波信号の測定を組み合わせる ことにより,レーザー超音波法による,プラント材料の内 部欠陥検出の信頼性が向上できるものと考えられる.

\section{参考文献}

1) H. Sato, S. Nakano, H. Ogiso, and K. Yamanaka: Jpn. J. Appl. Phys. 36 (1997) 3267.

2）落合誠, 仏円隆, 三浦 崇広, 黒田 英彦, 空本 誠喜, 兼本茂 : 日本原子力学会誌43 (2001) 275.

3）超音波便覽編集委員会編：超音波便覽(丸善,東京,平成11年) p. 374 .

4) C. B. Scruby and L. E. Drain: Laser Ultrasonics Techniques and Applications (Adam Hilger, Bristol, Philadelphia, and New York, 1990) p.261.

5) H. Nishino, Y. Tsukahara, H. Cho, and K. Yamanaka: Proc. IEEE Ultrason. Symp. 95, Seattle USA, (1995), p.673.

6) T. Tanaka and Y. Izawa: Jpn. J. Appl. Phys. 40 (2001) 1477.

7) R. J. Dewhurst and Q. Shan: Meas. Sci. Technol. 5 (1994) 655.

8) B. Rossi: Optics (Addison-Wesley Publishing Company, Inc., Massachusetts, Palo Alto, and London, 1957) p.197.

9) J. Krautkramer and H. Krautkramer: Ultrasonic Testing of Materials (Springer-Verlag, Berlin, 1977) p.620. 